\title{
DAMPAK KEBIJAKAN AKREDITASI TERHADAP PENINGKATAN KINERJA GURU MADRASAH (Studi di MI Nurul Muhsinin Desa Batujai)
}

\author{
Nujumuddin \\ Universitas Islam Negeri Mataram \\ e-mail: nujumuddin@uinmataram.ac.id
}

\begin{abstract}
Abstrak:Penelitian ini bertujuan untuk menggambarkan tentang upaya peningkatan kinerja guru sebagai dampak dari kebijakan akreditasi madrasah. Penelitian ini merupakan penelitian kualitatif diskriptif. Pengumpulan data melalui wawancara mendalam, observasi, dan dokumentasi serta dianalisis menggunakan model Miles dan Huberman. Hasil dari penelitian ini menggambarkan bahwa upaya peningkatkan kinerja para pelaku pendidikan dilakukan melalui kreatifitas dan inovasi para pelaku pendidikan baik kepala sekolah, para guru maupun staf administrasi, disamping itu juga dilakukan melalui program-program kerjasama madrasah dengan kementerian Agama dan Pemda setempat. Adapun program-program madrasah dalam mengoptimalkan kualitas tentu dengan menyiapkan berbagai sarana dan prasarana lembaga dan scara kontinyu melakukan pembinaan-pembinaan bagi seluruh komponen madrasah yang secara keseluruhan program madrasah mendapat apresiasi yang baik dari pihak yayasan maupun dari kalangan masyarakat dan pemerintah. Melalui peningkatan kinerja Guru dapat meningkatkan kualitas persiapan akeditasi.
\end{abstract}

Kata kunci: Kinerja guru, akreditasi madrasah, madrasah swasta

Title: Accreditation policy impact on teacher performance improvement (study at Madrasah Ibtidaiyyah Nurul Mubsinin, Batujai)

Author: Nujumuddin

Abstract: This study aims to illustrate how efforts to improve teacher performance as the impact of madrasa accreditation policies. This research is a descriptive qualitative research. Data collection through in-depth interviews, observation, and documentation and analyzed using the model of Miles and Huberman. The results of this study illustrate that efforts to improve the performance of education practitioners are carried out through the creativity and innovation of education practitioners both principals, teachers and administrative staff, besides that they are also carried out through madrasa collaboration programs with the Ministry of Religion and local government. The madrasa programs in optimizing the quality of course by preparing various facilities and infrastructure of institutions and continually provide guidance for all components of the madrasah which overall madrasa program received good appreciation from the foundation as well as from the community and government. Through improving the performance of the teacher can improve the quality of accreditation preparation.

Keywords: Teacher performance, madrasa accreditation, private madrasa

DOI: https://doi.org/10.20414/jpk.v15i1.1106 


\section{PENDAHULUAN}

Dalam Undang-Undang Sistem Pendidikan Nasional Nomor 20 Tahun 2003 pada pasal 3 yaitu "pendidikan nasional berfungsi mengembangkan kemampuan dan membentuk watak serta peradaban bangsa yang bermartabat dalam rangka mencerdaskan kehidupan bangsa, bertujuan untuk berkembangnya potensi peserta didik agar menjadi manusia yang beriman dan bertakwa kepada Tuhan Yang Maha Esa, berakhlak mulia, sehat, berilmu, cakap, kereatif, mandiri dan menjadi warga Negara yang demokratis serta bertanggung jawab.”"

Pendidikan merupakan salah satu pranata sosial yang sangat penting dalam upaya mencerdaskan bangsa bagi tercapainya kehidupan masyarakat maju, demokratis, mandiri dan sejahtera. Pendidikan pada hakekatnya adalah usaha memberdayakan manusia. Manusia itu sendiri adalah pribadi yang utuh dan kompleks sehingga sulit dipelajari dengan tuntas. Oleh karena demikian, masalah pendidikan tidak akan pernah selesai untuk dibicarakan, sebab manusia itu sendiri selalu berkembang mengikuti dinamika kehidupanya.

Pendidikan di Indonesia dihadapkan pada masalah yang cukup kompleks, diantaranya adalah rendahnya mutu pendidikan pada jenjang dan satuan pendidikan khususnya pada pendidikan dasar dan menengah. Berbagai upaya dilakukan untuk meningkatkan mutu pendidikan nasional baik oleh pemerintah maupun masyarakat. Diantara upaya peningkatan tersebut adalah melaui berbagai pelatihan dan peningkatan kualifikasi guru, penyempurnaan kurikulum, peningkatan mutu manajemen madrsah, pengadaan buku dan alat pelajaran, perbaikan sarana dan prasarana pendidikan lainnya, serta pelaksanaan akreditasi. Namun demikian, berbagai indikator mutu pendidikan belum menunjukkan peningkatan yang merata. $^{2}$

Pembaharuan pendidikan dilakukan terus menerus agar mampu menghadapi berbagai tantangan sesuai dengan perkembangan zamannya. Dalam era reformasi dan demokratisasi pendidikan, tantangan yang dihadapi oleh dunia pendidikan meliputi persoalan-persoalan yang terkait dengan pemerataan, mutu, relevansi, dan efisiensi pendidikan ${ }^{3}$. Dalam rangka menjembatani persoalan-persoalan tersebut secara opitmal, perlu dilakukan visitasi dan evaluasi lembaga pendidikan sebagaimana diatur oleh undang-undang, baik yang berkaitan dengan sarana dan prasana pendidikan, biaya pendidikan, tenaga pengajar, kurikulum, dan

${ }^{1}$ Undang-Undang RI No. 20 Tabun 2003 Tentang Sistem Pendidikan Nasional, (Jakarta: Asamandiri, 2003), h. 241

2 Departemen Pendidikan Nasional, Manajemen Peningkatan Mutu Berbasis Madrasah, (Jakarta: Direktorat Jenderal Pendidikan dasar dan Menengah, 2002), h. 12

3 Departemen Agama RI. Pedoman Akreditasi Madrasah. (Jakarta: Direktorat Jenderal Kelembagaan Agama Islam Depag RI, 2005), h. 4 
komponen pendidikan lainnya. ${ }^{4}$ Visitasi dan evaluasi ini dilakukan dalam rangka akreditasi madrasah.

Akreditasi sekolah/madrasah adalah sebuah proses penilaian secara komprehensif terhadap kelayakan satuan lembaga atau program pendidikan, yang hasilnya diwujudkan dalam bentuk sertifikat pengakuan dan peringkat kelayakan yang dikeluarkan oleh suatu lembaga yang mandiri dan profesional. Kegiatan penilaian kelayakan dan kinerja suatu sekolah berdasarkan kriteria (standar) yang telah ditetapkan dan dilakukan oleh Badan Akreditasi Sekolah Nasional (BASNAS) yang hasilnya diwujudkan dalam bentuk pengakuan peringkat kelayakan sebagaimana diatur dalam Keputusan Menteri Pendidikan Nasional Nomor 087/U/2002.

Dengan demikian, hasil dari akreditasi adalah pengakuan "terakreditasi" atau "tidak terakreditasi”. Bagi sekolah yang terakreditasi diklasifikasi menjadi tiga tahapan, yaitu: (1) A (Amat Baik) dengan nilai antara 86-100; (2) B (Baik) dengan nilai antara 71-85; (3) C (Cukup) dengan nilai antara 56-70. Jika nilai tersebut kurang dari 56 maka sekolah tersebut tidak layak untuk mendapatkan pengakuan "terakreditasi".

Beberapa hal yang harus diperhatikan oleh pihak sekolah mengenai masa berlaku akreditasi yang telah diperolehnya, antara lain: (1) Peringkat akreditasi berlaku selama 4 tahun terhitung sejak ditetapkannya peringkat akreditasi; (2) Sekolah wajib mengajukan permohonan reakreditasi yaitu 6 bulan sebelum masa akreditasi berakhir, (3) Sekolah yang meghendaki reakreditasi bisa mengajukan permohonan sekurang-kurangnya 1 atau 2 tahun setelah penetapan akreditasi, (4) Sekolah yang masa akreditasinya telah berakhir dan sudah mengajukan permohonan reakreditasi namun belum ditindaklanjuti maka sekolah tersebut masih menggunakan peringkat akreditasi terdahulu, (5) Sekolah yang masa akreditasnya berakhir dan menolak untuk reakreditasi maka peringkat akreditasi yang terdahulu sudah tidak berlaku.

Penyelenggaraan akreditasi sebagai salah satu kegiatan peningkatan mutu di bidang pendidikan, pada hakikatnya adalah agar penyelenggaraan pendidikan dapat mencapai standar kualitas yang ditetapkan dan pada gilirannya peserta didik dapat mencapai keberhasilan baik dalam penguasaan ilmu pengetahuan, keterampilan maupun dalam pembentukan kepribadian. ${ }^{5}$ Akreditasi adalah suatu kegiatan penilaian kelayakan suatu madrasah berdasarkan kriteria yang telah ditetapkan dan dilakukan oleh Badan Akreditasi Sekolah yang hasilnya akan diwujudkan dalam bentuk pengakuan peringkat kelayakan. ${ }^{6}$

${ }^{4}$ Abdul Rachman Shaleh, Pendidikan Agama dan Pembangunan watak Bangsa (Jakarta: Grafindo Persada, 2005), h. 17

${ }^{5}$ Mulyono, Manajemen Administrasi..., h. 266

${ }^{6}$ Himpunan Keputusan Menteri Pendidikan Nasional RI, (Jakarta: Sinar Grafika, 2008), h. 118 
Di dalam proses akreditasi dievaluasi dalam kaitannya dengan arah dan tujuannya, serta didasarkan pada keseluruhan kondisi madrasah sebagai sebuah institusi belajar. Walaupun beragam perbedaan terjadi antar madrasah, tetapi madrasah dievaluasi berdasarkan standar tertentu. Standar diharapkan dapat mendorong dan menciptakan suasana kondusif bagi pertumbuhan dan memberikan rangsangan untuk terus berusaha mencapai mutu yang diharapkan.

Pada era sekarang dengan pertumbuhan informasi yang cepat terkadang tidak dapat dikendalikan untuk meraih keberhasilan lembaga pendidikan. kemampuan untuk mengelola informasi untuk pengambilan keputusan yang membawa keberhasilan organisasi adalah sangat penting. Kata yang penting dalam hal ini menurut Sulisworo ${ }^{7}$ adalah performansi. Performansi atau kinerja merupakan kata yang mempunyai makna penting bagi pengelolaan pendidikan dewasa ini.

Kinerja merupakan sesuatu yang sangat dibutuhkan dan bisa bermacammacam, berkembang dan berubah bahkan seringkali tidak disadari oleh pelakunya. Seseorang bekerja karena ada sesuatu yang hendak dicapainya dan orang berharap bahwa aktivitas kerja yang dilakukannya akan membawa kepada suatu keadaan yang lebih memuaskan daripada keadaan sebelumnya. ${ }^{8}$

Pengukuran kinerja juga digunakan untuk menilai pencapaian tujuan dan sasaran (goal and objective). Elemen kunci dari sistem pengukuran kinerja terdiri atas: 1). Perencanaan dan penetapan tujuan, 2). Pengembangan ukuran yang relevan, 3). Pelaporan format atas hasil, dan 4). Penggunaan informasi.

Menurut Sulisworo ${ }^{9}$ dalam pengelolaan lembaga pendidikan, pengukuran kinerja haruslah fokus pada pembelajaran siswa. Untuk mencapai hal tersebut diperlukan sistem yang berbasis pada fakta yang komprehensif dan terintegrasi. Sistem ini mencakup data input, data lingkungan, data kinerja, data kompetisi, dan lainnya.

Pengukuran kinerja guru dalam sebuah oerganisasi/madrasah haruslah fokus pada hasilhasil kunci. Hasil-hasil tersebut dapat digunakan untuk menciptakan nilai bagi siswa dan untuk para stakeholder kunci. Dengan menciptakan nilai bagi siwa dan para stakeholder, lembaga pendidikan dapat berkontribusi pada peningkatan kinerja pendidikan keseluruhan dan juga loyalitas. Selain itu, pengukuran kinerja digunakan pula dalam pengambilan keputusan yang berbasis fakta untuk menentukan dan menyesuaikan arah madrasah dan sumber daya yang digunakan di ruang kelas dan semua proses penting yang diselenggarakan pleh madrasah.

${ }^{7}$ Dwi Sulisworo, manajemen dan Evaluasi Kinerja Lembaga Pendidikan dengan Balanced Score Card, (Semarang: PT. Sindur Press), h. 1

8 Anoragra. Psikologi Industri dan Sosial, (Jakarta: Dunia Pustaka Jaya, 1998), h. 55

${ }^{9}$ Dwi Sulisworo, Manajemen dan Evaluasi Kinerja....., h. 2 
Tugas guru yang sangat dominan dalam proses belajar mengajar menuntut adanya pengembangan kualitas kinerja guru. Guru yang profesional dan kompeten hendaknya tidaklah langsung didapat dari ijazah pendidikan guru, namun harus belajar terus dari pengalaman, pengetahuan dan keterampilan tersendiri, perbaikan mengajar dilakukan secara berkelanjutan. ${ }^{10}$

Oleh sebab itu, pengembangan guru tidak terbatas melalui pengalaman mengajar masing-masing, tapi dengan mengikuti berbagai aktivitas yang menunjang profesionalitasnya sebagai seorang tenaga pendidik melalui kelompok kerja guru, penataran-penataran, seminarseminar maupun melalui studi lanjut ke perguruan tinggi.

Dalam proses aktivitasnya guru perlu diukur kinerjanya secara konperhensif untuk mendapatkan informasi yang valid mengenai keberhasilan atau kegagalannya. Hal demikian dilakukan guna mengetahui tingkat ketercapaian indikator kinerja guru yang telah ditetapkan, terutama yang menyangkut ketercapaian sasaran pengajaran.

Ketercapaian indikator kinerja merupakan proses identifikasi dan klasifikasi indikator kinerja melalui sistem pemgumpulan dan pengolahan data atau informasi untuk menentukan pencapaian tingkatan kinerja kegiatan atau program. Penetapan indikator kinerja tersebut didasarkan pada kelompok menurut masukan (input), keluaran (output), hasil (outcome), manfaat (benefit) dan dampak (infact), serta indikator proses jika diperlukan untuk menunjukkan proses manajemen kegiatan yang telah terjadi.

Laju perkembangan suatu rumah tangga perusahaan dalam rangka pembangunan bangsa menurut Alma ${ }^{11}$ ditentukan oleh kemampuan investasi, mutu produksi, efisiensi dan efektivitas, mutu pelayanan, dan profesionalisme. Semua masalah di atas terfokus sentral pada sumber daya manusia yang dibentuk melaui jasa pendidikan. Mc. Lelland telah mengadakan studi panjang di Jepang dan beberapa negara lain, dan hasilnya menunjukkan bahwa kunci kemajuan suatu pembangunan ekonomi termasuk perusahaan adalah need for achievement, dorongan untuk berprestasi.

Sebagai contoh Jepang dan Korea, keberhasilan dalam pembangunan ekonominya terletak pada keuletan, kesungguhan, kecermatan, ketekunan, kemampuan dalam memahami persoalan dan dalam mencari pemecahan yang tepat terhadap permasalahan yang dihadapi. Semua sifat-sifat ini dapat terbentuk dalam proses pendidikan yang harus dilatih oleh guru setiap hari.

Melihat realita ini, maka guru di Indonesia harus merasa iri dengan keadaan dan kinerja guru yang mampu menghasilkan lulusan yang berdaya saing secara global. Untuk itu

10 Mainudin, Pengembangan dan Pelaksanaan Kurikulum yang Menjamin Tercapainya Lulusan yang Kreatif dalam Konvensi Nasional,(Jakarta: Gramedia Wicaksana, 1994), h. 23

${ }^{11}$ Buchari Alma, manajemen Corporate dan Strategi Pemasaran Jasa Pendidikan; Fokus Pada Mutu dan Layanan Prima,(bandung: Al-Fabeta, 2008), h. 18 
diperlukan sosok guru yang memiliki motivasi kerja yang baik; rajin bekerja untuk tanah air, sangat setia kepada atasannya, menghargai lembaga pendidikan tempat ia bekerja, dan tidak berpura-pura tapi betul-betul mengajar dari lubuk hati yang paling dalam.

Motivasi kerja adalah sesuatu yang menimbulkan semangat atau dorongan kerja atau dorongan yang sangat kuat dalam menentukan terwujudnya suatu perbuatan yang direncanakan. Dorongan itu dapat berupa imbalan atau adanya ancaman. Dorongan juga dapat terjadi sebagai bagian dari kesadaran jiwa yang diimbangi oleh harapan terhadap sesuatu yang akan dicapai. ${ }^{12}$

Berdasakan hasil observasi pada MI Nurul Muhsinin Desa Batujai, bahwa MI ini belum terakreditasi, sehingga belum diketahui kondisi riil mengenai kualitas dan kuantitas lembaga ini ${ }^{13}$, oleh karenanya, madrasah ini sebagai salah satu bagian dari sistem pendidikan nasional dituntut untuk selalu berupaya meningkatkan kualitas dalam penyelenggaraan pendidikan. Salah satu upaya untuk meningkatkan kualitas penyelenggaran pendidikan sebagaimana dimaksud di atas adalah dengan meningkatkan kinerja guru, sehingga dapat menghasilkan lulusan yang berkualitas, mampu bersaing serta mampu menghadapi tantangan zaman, dan peningkatan kinerja guru inilah yang akan menjadi bahan kajian dalam penelitian ini, dengan demikian peneliti akan mengupas secara detail urgensi akreditasi dalam mengoptimalkan kinerja guru di MI Nurul Muhsinin Batujai.

\section{METODE PENELITIAN}

Penelitian ini merupakan penelitian kualitatif diskriptif, dimana wilayah kajiannya bersifat empiris dan realistis, sehingga hasilnya diharapkan berupa data-data faktual. Peneliti menggunakan beberapa teknik pengumpulan data, yaitu wawancara mendalam, observasi, dan dokumentasi. Teknik analisis data yang digunakan dalam penelitian ini menggunakan model Miles dan Huberman, yang terdiri dari tiga alur kegiatan atau proses yang terjadi secara bersamaan, yakni: reduksi data, penyajian data, dan penarikan kesimpulan/verifikasi.

\section{HASIL PENELITIAN DAN PEMBAHASAN}

\section{Eskalasi Kinerja Guru dan pegawai di MI Nurul Muhsinin}

Kinerja merefleksikan kesuksesan suatu organisasi, maka dipandang penting untuk mengukur karakteristik tenaga kerjanya. Kinerja guru merupakan kulminasi dari tiga elemen yang saling berkaitan yakni keterampilan, upaya sifat keadaan dan kondisi eksternal. Tingkat keterampilan merupakan bahan mentah yang dibawa seseorang ke tempat kerja seperti pengalaman, kemampuan, kecakapan-kecakapan antar pribadi serta

\footnotetext{
12 Hikmat, Manajemen Pendidikan, (Bandung : Pustaka Setia, 2009), h. 272

13 Observasi tanggal 15 September 2018
} 
kecakapan tehknik. Upaya tersebut diungkap sebagai motivasi yang diperlihatkan karyawan untuk menyelesaikan tugas pekerjaannya. Sedangkan kondisi eksternal adalah tingkat sejauh mana kondisi eksternal mendukung produktivitas kerja.

Kinerja dapat dilihat dari beberapa kriteria: (1). Karakteristik individu, (2). Proses, (3). Hasil dan (4) Kombinasi antara karakter individu, proses dan hasil. Kinerja seseorang dapat ditingkatkan bila ada kesesuaian antara pekerjaan dengan keahliannya, begitu pula halnya dengan penempatan guru pada bidang tugasnya. Menempatkan guru sesuai dengan keahliannya secara mutlak harus dilakukan. Bila guru diberikan tugas tidak sesuai dengan keahliannya akan berakibat menurunnya cara kerja dan hasil pekerjaan mereka, juga akan menimbulkan rasa tidak puas pada diri mereka. Rasa kecewa akan menghambat perkembangan moral kerja guru. Moral kerja positif ialah suasana bekerja yang gembira, bekerja bukan dirasakan sebagai sesuatu yang dipaksakan melainkan sebagai sesuatu yang menyenangkan. Moral kerja yang positif adalah mampu mencintai tugas sebagai suatu yang memiliki nilai keindahan di dalamnya. Jadi kinerja dapat ditingkatkan dengan cara memberikan pekerjaan seseorang sesuai dengan bidang kemampuannya. Kemampuan bersama-sama dengan bakat merupakan salah satu faktor yang menentukan prestasi individu, sedangkan prestasi ditentukan oleh banyak faktor diantaranya kecerdasan.

Kinerja dipengaruhi juga oleh kepuasan kerja yaitu perasaan individu terhadap pekerjaan yang memberikan kepuasan bathin kepada seseorang sehingga pekerjaan itu disenangi dan digeluti dengan baik. Untuk mengetahui keberhasilan kinerja perlu dilakukan evaluasi atau penilaian kinerja dengan berpedoman pada parameter dan indikator yang ditetapkan yang diukur secara efektif dan efisien seperti produktivitasnya, efektivitas menggunakan waktu, dana yang dipakai serta bahan yang tidak terpakai. Sedangkan evaluasi kerja melalui perilaku dilakukan dengan cara membandingkan dan mengukur perilaku seseorang dengan teman sekerja atau mengamati tindakan seseorang dalam menjalankan perintah atau tugas yang diberikan, cara mengkomunikasikan tugas dan pekerjaan dengan orang lain. Dalam melakukan evaluasi kinerja seseorang dapat dilakukan dengan menggunakan kriteria yaitu: dengan hasil tugas.

Hasil tugas, evaluasi hasil tugas adalah mengevaluasi hasil pelaksanaan kerja individu dengan beberapa kriteria (indikator) yang dapat diukur. Evaluasi perilaku dapat dilakukan dengan cara membandingkan perilakunya dengan rekan kerja yang lain dan evaluasi ciri individu adalah mengamati karaktistik individu dalam berprilaku maupun berkerja, cara berkomunikasi dengan orang lain.

Dari uraian diatas beberapa indikator kinerja guru antara lain:

a. Kemampuan membuat perencanaan dan persiapan mengajar. Perencanaan mengajar yang disiapkan oleh guru pada MI Nurul Muhsinin berdasar hasil penelitian meliputi 
RPP, media, buku paket, dan alat bantu pembelajaran yang diharapkan dapat menunjang pencapaian tujuan pembelajaran.

b. Penguasaan materi yang akan diajarkan kepada siswa. Guru tidak hanya bertindak sebagai pengajar, namun lebih dari itu ia merupakan penanggung jawab perkembangan anak dalam masa-masa kehidupan mereka di sekolah. Pada MI Nurul Muhsinin, guru disamping dituntut menguasai materi pelajaran yang akan diajarkan kepada siswa, para guru juga dituntut memiliki kematangan intelektual, kedewasaan dan wawasan berfikir yang diharapkan mampu membentuk kepribadian siswa menjadi pribadi yang dewasa, yang mampu bertanggung jawab, baik kepada dirinya sendiri, keluarga, masyarakat dan tanggung jawab kepada Allah Swt.

c. Penguasaan metode dan strategi mengajar. Salah satu kunci keberhasilan guru dalam mengajar dan menanamkan nilai-nilai kepribadian kepada siswa adalah guru menguasai metode yang akan digunakan dalam proses belajar mengajar. Guru yang menggunakan metode yang bervariasi pada umumnya lebih dominan menjadikan siswa termotivasi dalam belajar, sebab metode yang monoton cenderung menjadikan siswa menjadi pasif dan kreatif. Oleh karenanya guru dituntut menguasai metode dan strategi pembelajaran, sehingga perencanaan, proses dan hasil belajar siswa dapat tercapai secara optimal. Demikian halnya dengan para guru di MI Nurul Muhsinin, juga dituntut menguasai berbagai metode dan strategi pembelajaran dalam melaksanakan pembelajaran di sekolah. Hal ini dimaksudkan disamping agar proses belajar mengajar berjalan dengan lebih maksimal, juga diharapkan para siswa diberi pengalaman mengenai bagaimana menerapkan metode dan strategi yang bervariasi, sehingga secara tidak langsung pada siswa juga tertanam kreatifitas mereka dalam belajar.

d. Pemberian tugas-tugas kepada siswa. Untuk melatih siswa dalam membaca dan menulis ilmiah, sekaligus untuk memperkaya cakrawala keilmuan mereka, pada guru dituntut memberikan tugas mandiri kepada siswa untuk dikerjakan secara individu maupun kelompok, apalagi saat ini bahwa kurikulum 2013 menuntut siswa memiliki kemandirian dalam memperlajari, mengkaji dan menguasai materi-materi (tema-tema) pelajaran di sekolah. Oleh karenanya pemberian tugas pada siswa di MI Nurul Muhsinin juga diterapkan dalam rangka membiasakan siswa pendalaman materi-materi pelajaran yang telah diberikan oleh guru. Dalam pelaksanaannya para siswa diminta untuk mencari literatur-literatur yang sudah ditentukan oleh guru untuk menyelesaikan tugas-tugas mereka.

e. Kemampuan mengelola kelas. Mengelola kelas merupakan salah satu dari sembilan keterampilan dasar mengajar yang harus dimiliki oleh guru. Pengelolaan kelas merupakan keterampilan yang wajib dimiliki oleh guru. 
Sebuah proses belajar mengajar akan dapat menuai hasil optimal tidak hanya sekedar karena metode, strategi dan fasilitas yang memadai. Apabila seluruh fasilitas tersedia, namun kemampuan guru dalam mengelola kelas tidak ada (minim), maka sangat mungkin kelas yang bersangkutan tidak akan dapat mencapai tujuan secara optimal. Kondisi ini juga menjadi perhatian pada MI Nurul Muhsinin, bahwa para guru, melalui pelatihan-pelatihan yang diikuti dan melalui diskusi internal para pelaksana pendidikan di MI Nurul Muhsinin juga melakukan hal yang sama, dimana mereka dituntut dan dibiasakan untuk mengelola kelas dengan sebaik-baiknya, sehingga proses belajar mengajar dapat berjalan secara optimal.

Kemampuan melakukan penilaian dan evaluasi. Keterampilan yang tidak kalah pentingnya yang harus dimiliki oleh guru adalah kemampuan melakukan evaluasi. Menurut waktunya, evaluasi dapat dilakukan melalui tiga tahap yakni penilaian di awal, penilaian pada proses dan penilaian di akhir pembelajaran. Penilaian awal ini yang biasa kita kenal dengan istilah pre test, yakni penilaian yang dilakukan sebelum proses belajar mengajar dilakukan, tes ini dimaksudkan untuk mengetahui sampai dimana peahaman siswa terhadap peguasaan materi yang telah mereka pelajari pada pertemuan sebelumnya. Tes awal ini dimaksudkan agar dapat menentukan apakah guru dapat melanjutkn materi berikutnya ataukah akan mengulangi lagi materi yang sudah diajarkan pada pertemuan sebelumnya.

Penilaian berikutnya adalah penilaian proses. Penilaian proses ini dimaksudkan untuk memonitoring daya tangkap siswa selama mengikuti proses belajar mengajar di kelas. Tes ini biasanya dilakukan secara lisan atau dengan memberikan tugas kepada siswa untuk diselesaikan pada saat berlangsungnya proses belajar mengajar.

Adapun penilaian terakhir yang dilakukan adalah penilaian/evaluasi sumatif. Penilaian ini dimaksudkan untuk mengukur sejauhmana penguasaan siswa terhaap materi pelajaran yang telah ditempuh dalam satu jenjang waktu tertentu. Tes (evaluasi) sumatif ini dijadikan sebagai dasar/pijakan dalam mengambil keputusan apakah siswa tertentu berhak untuk naik pada kelas/jenjang tertentu atau tidak. Hal demikian juga yang

dilaksanakan pada MI Nurul Muhsinin sebagaimana lembaga-lembaga formal pada umumnya.

\section{Optimalisasi Program Madrasah}

Peningkatan kinerja guru pada MI Nurul Muhsinin dilakukan melalui berbagai program diantaranya: (a) Pelatihan-pelatihan kependidikan yang menunjang potensi dan kapasitas tenaga pendidik. Pelatihan kependidikan yang diikuti oleh para guru adalah pelatihan penerapan kurikulum 2013 yang dilaksanakan secara internal dengan narasumber tiga orang guru yang pernah mengikuti pelatihan ini yakni Bapak Naskur, Ibu 
Nurainah dan Ibu Masni. Para guru yang pernah mengikuti pelatihan K13 baik di dalam maupun luar daerah menjadi tutor bagi guru yang belum mengikuti kegiatan ini. Menurut kepala sekolah MI Nurul Muhsinin, sampai saat ini seluruh guru di MI Nurul Muhsinin telah mengikuti program pelatihan Kurikulum 2013, sehingga kemampuan para guru hampir rata-rata mampu menerapkan kurikulum ini. ${ }^{14}$ (b) Diskusi guru bersama kepala sekolah, wakasek dan tenaga administrasi. Sebagai upaya mengoptimalkan kinerja seluruh tenaga kependidikan di MI Nurul Muhsinin, lembaga ini secara rutin mengadakan diskusi internal dikalangan pengelola madrasah dan para guru. Diskusi ini dilaksanakan setiap minggu pertama awal bulan dengan topik yang berbeda-beda sesuai dengan program, masalah dan progres kegiatan lembaga. Diskusi ini dilaksanakan dalam rangka memecahkan berbagai persoalan yang dihadapi oleh para pelaku pendidikan, baik kepala madrasah, wakil kepala madrasah, para guru maupun staf Tata Usaha.

\section{Faktor pendukung dan penghambat optimalisasi kinerja guru}

Beberapa Faktor Pendukung optimalisasi kinerja guru pada MI Nurul Muhsinin adalah: (1) Tenaga pendidik (guru) yang memiliki kualifikasi Sarjana (S1), (2) Sarana dan prasarana yang memadai; (3) Dukungan keluarga besar Yayasan Nurul Muhsinin; (4) Dukungan dari masyarakat sekitar dan kalangan keluarga siswa, (5) Dukungan pihak pemerintah dalam hal ini pemda dan kemenag; (6) Keinginan kuat untuk memperoleh akreditasi A.

Adapun Faktor Penghambat optimalisasi kinerja guru pada MI Nurul Muhsinin adalah: (1) Kegiatan-kegiatan pelatihan untuk peningkatan kapasitas masih sangat sedikit dilaksanakan oleh lembaga, (2) Kerjasama dengan lembaga-lembaga selain kemenag dan Pemda masih belum banyak dilakukan; (3) Motivasi para pelaksana pendidikan belum optimal, (4) Para pelaksana pendidikan masih disibukkan dengan rutininas di luar tugas pokoknya sebagai guru.

Dari beberapa faktor penghambat di atas, perlu segera diambil tindakan sebagai upaya progresif dan aktif, mulai dari pembenahan manajemen, administrasi, membangun kerja sama dengan lembaga-lembaga donor (founding), lembaga pendidikan dan pelatihan baik lembaga pemerintah maupun swasta dengan harapan kesejahteraan para pelaksana pendidikan lebih diperhatikan, karena hal ini sangat memberi pengaruh pada kualitas para pelaku pendidikan yang implikasinya adalah capaian akreditasi yang belum bisa maksimal (mencapai akreditasi A). 


\section{Urgensi akreditasi madrasah bagi peningkatan kinerja guru}

Akreditasi merupakan program pemerintah bagi semua lembaga pendidikan dalam rangka menjamin dan menjaga kualitas pendidikan, baik dari sisi manajemen, proses, output maupun outcome yang diharapkan mampu berkompetisi dalam lingkup regional, nasional dan internasional, sehingga dunia pendidikan di Indonesia mampu menempati posisi yang tidak kalah kualitasnya dengan lembaga pendidikan di negara lain.

Berdasarkan Keputusan Menteri pendidikan Nasional Nomor 087/U/2002, akreditasi sekolah mempunyai tujuan, yaitu: (1) memperolah gambaran kinerja sekolah sebagai alat pembinaan, pengembangan, dan peningkatan mutu; (2) menentukan tingkat kelayakan suatu sekolah dalam penyelenggaraan pelayanan pendidikan.

a. Tujuan Akreditasi Sekolah/Madrasah

Akreditasi sekolah/madrasah bertujuan untuk:

1) Memberikan informasi tentang kelayakan sekolah/madrasah atau program yang dilaksanakannya berdasarkan Standar Nasional Pendidikan.

2) Memberikan pengakuan peringkat kelayakan.

3) Memberikan rekomendasi tentang penjaminan mutu pendidikan kepada program dan atau satuan pendidikan yang diakreditasi dan pihak terkait.

Bagi para guru, hasil akreditasi sekolah/madrasah merupakan dorongan bagi guru untuk selalu meningkatkan diri dan bekerja keras untuk memberikan layanan yang terbaik bagi peserta didiknya. Secara moral, guru senang bekerja di sekolah/madrasah baik yang di akui sebagai sekolah/madrasah baik, oleh karena itu, guru selalu beruasaha untuk meningkatkan diri dan bekerja keras untuk mempertahankan dan meningkatkan mutu sekolah/madrasah.

Dalam rangka menempatkan program akreditasi sebagai bagian dari upaya sekolah/madrasah untuk meningkatkan mutunya secara berkelanjutan, maka sistem akreditasi dikembangkan dengan karakteristik yang memberikan: (a) Keseimbangan antara fokus penilaian kelayakan dan kinerja sekolah/madrasah; (b) Keseimbangan antara penilaian internal melalui evaluasi diri oleh sekolah/madrasah dan evaluasi eksternal oleh asesor. Keseimbangan hasil akreditasi antara pemeringkatan status sekolah/madrasah dan umpan balik untuk peningkatan mutu sekolah/madrasah;

b. Fungsi Akreditasi Sekolah/Madrasah

Dengan menggunakan instrumen akreditasi yang komprehensif, hasil akreditasi diharapkan dapat memetakan secara utuh profil sekolah/madrasah. Proses akreditasi sekolah/madrasah berfungsi untuk:

1) Pengetahuan, yaitu sebagai informasi bagi semua pihak tentang kelayakan sekolah/madrasah dilihat dari berbagai unsur terkait yang mengacu pada standar minimal beserta indikator-indikator. 
2) Akuntabilitas, yaitu sebagai bentuk pertanggung jawaban sekolah/madrasah kepada publik, apakah layanan yang dilakukan dan diberikan oleh sekolah/madrasah telah memenuhi harapan atau keinginan masyarakat.

3) Pembinaan dan pengembangan, yaitu sebagai dasar bagi sekolah/madrasah, pemerintah, dan masyarakat dalam upaya peningkatan atau pengembangan mutu sekolah/madrasah.

c. Komponen Akreditasi Sekolah/Madrasah

1) Kurikulum dan Proses Pembelajaran

2) Administrasi dan Manajemen Sekolah/Madrasah

3) Oraganisasi dan Kelembagaan Sekolah/ Madrasah

4) Standar organisasi dan kelembagaan mencakup dua hal utama, yaitu organisasi dan legalitas serta regulasi sekolah/madrasah.

5) Organisasi

6) Legalitas dan Regulasi Sekolah/Madrasah

7) Sarana dan Prasarana

8) Ketenagaan

\section{SIMPULAN}

Upaya peningkatkan kinerja para pelaku pendidikan dilakukan melalui kreatifitas dan inovasi para pelaku pendidikan baik kepala sekolah, para guru maupun staf administrasi, disamping itu juga dilakukan melalui program-program madrasah bekerjasama dengan kementerian Agama dan Pemda setempat.

Program-program madrasah dalam mengoptimalkan kualitas tentu dengan menyiapkan berbagai sarana dan prasarana lembaga dan scara kontinyu melakukan pembinaan-pembinaan bagi sluruh komponen madrasah yang secara keseluruhan program madrasah mendapat apresiasi yang baik dari pihak yayasan maupun dari kalangan masyarakat dan pemerintah. Dengan demikian urgensi akreditasi madrasah bagi peningkatan kinerja guru pada MI Nurul Muhsinin cukup memberi warna dengan melengkapi standar-standar yang dapat menjadikan madrasah sebagai lembaga yang layak mendapat penghargaan melalui akreditasi.

Dalam rangka mencapai akreditasi yang optimal, lembaga dituntut untuk mengoptimalkan berbagai komponen madrasah, sehingga kinerja guru dapat terlaksana secara optimal. Untuk mencapai kinerja optimal tersebut dibutuhkan managemen yang tepat, sehingga seluruh komponen dapat mencapai tujuan bersama yang diharapkan. 


\section{DAFTAR PUSTAKA}

Shaleh, Abdul Rachman. 2005. Pendidikan Agama dan Pembangunan watak Bangsa. Jakarta: Grafindo Persada.

Anoraga. 1998. Psikologi Industri dan Sosial. Jakarta: Dunia Pustaka Jaya.

Alma. Buchari. 2008. Manajemen Corporate dan Strategi Pemasaran Jasa Pendidikan; Fokus Pada Mutu dan Layanan Prima. Bandung: Al-Fabeta.

Departemen Agama RI. 2005. Pedoman Akreditasi Madrasah. Jakarta: Direktorat Jenderal Kelembagaan Agama Islam Depag RI.

Departemen pendidikan Nasional. 2002. Manajemen peningkatan Mutu Berbasis Madrasah, Jakarta: Direktorat Jenderal Pendidikan dasar dan Menengah.

Dinas pendidikan dan Kebudayaan. 2005. Akreditasi Madrasah dan Pembelajaran Tematik Semaramg: Grafindo Persada.

Sulisworo, Dwi. t.t. Manajemen dan Evaluasi Kinerja Lembaga Pendidikan dengan Balanced Score Card. Semarang: Sindur Press.

Uno, Hamzah B. 2007. Profesi Kependidikan; Problema, Solusi, dan Reformasi Pendidikan di Indonesia. Jakarta: Bumi Aksara.

Hikmat. 2009. Manajemen Pendidikan. Bandung: Pustaka Setia.

Himpunan Keputusan Menteri Pendidikan Nasional RI. 2008. Jakarta: Sinar Grafika.

Mainudin. 1994. Pengembangan dan Pelaksanaan Kurikulum yang Menjamin Tercapainya Lulusan yang Kreatif dalam Konvensi Nasional, Jakarta: Gramedia Wicaksana.

Mulyono. 2009. Manajemen Administrasi dan Organisasi Pendidikan. Jogjakarta: Ar-Ruzz Media. 